\title{
Assessment of Undiscovered Continuous Oil and Shale-Gas Resources in the Bazhenov Formation of the West Siberian Basin Province, Russia, 2016
}

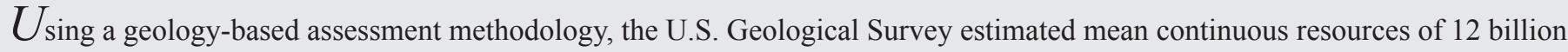
barrels of oil and 75 trillion cubic feet of gas in the Bazhenov Formation of the West Siberian Basin Province, Russia.

\section{Introduction}

The U.S. Geological Survey (USGS) quantitatively assessed the potential for undiscovered, technically recoverable continuous oil and shale-gas resources in the West Siberian Basin Province of Russia (fig. 1). This study focuses on the geologic evaluation and assessment of oil and gas source-reservoir rock systems and potential resources of the Upper Jurassic Bazhenov Formation.

For this study, the USGS defined continuous oil and shale-gas source-reservoir rock systems. These systems (1) contain at least 2 weight percent or more total organic carbon, (2) occur within the thermal maturity window for oil or natural gas generation, (3) have 15 meters or more of organic-rich shale, and (4) contain Type I or Type II organic matter (Charpentier and Cook, 2011). Many studies have been published on the Bazhenov Formation, providing information on source rock characteristics, tectonic history, thermal history, and timing of maturation and generation of hydrocarbons. Several oil fields in the southern part of the West Siberian Basin Province produce continuous oil from the Bazhenov Formation (for example, Salym Field; Clarke and Rachlin, 1980). At the time of this study, no fields are known to produce shale gas from the Bazhenov Formation.

Two assessment units (AUs) were defined for this study (fig. 1). The Bazhenov Continuous Oil AU was delineated in the southern part of the basin where the Bazhenov source rock is thermally mature with respect to oil generation. The Bazhenov Shale Gas AU was delineated in the northern part of the province where the Bazhenov source rock is deeper and is presumably thermally mature with respect to gas generation.

Because detailed production data for continuous resources outside of the United States are difficult to obtain, the USGS assessment methodology uses analogs of continuous oil and shale-gas accumulations from the United

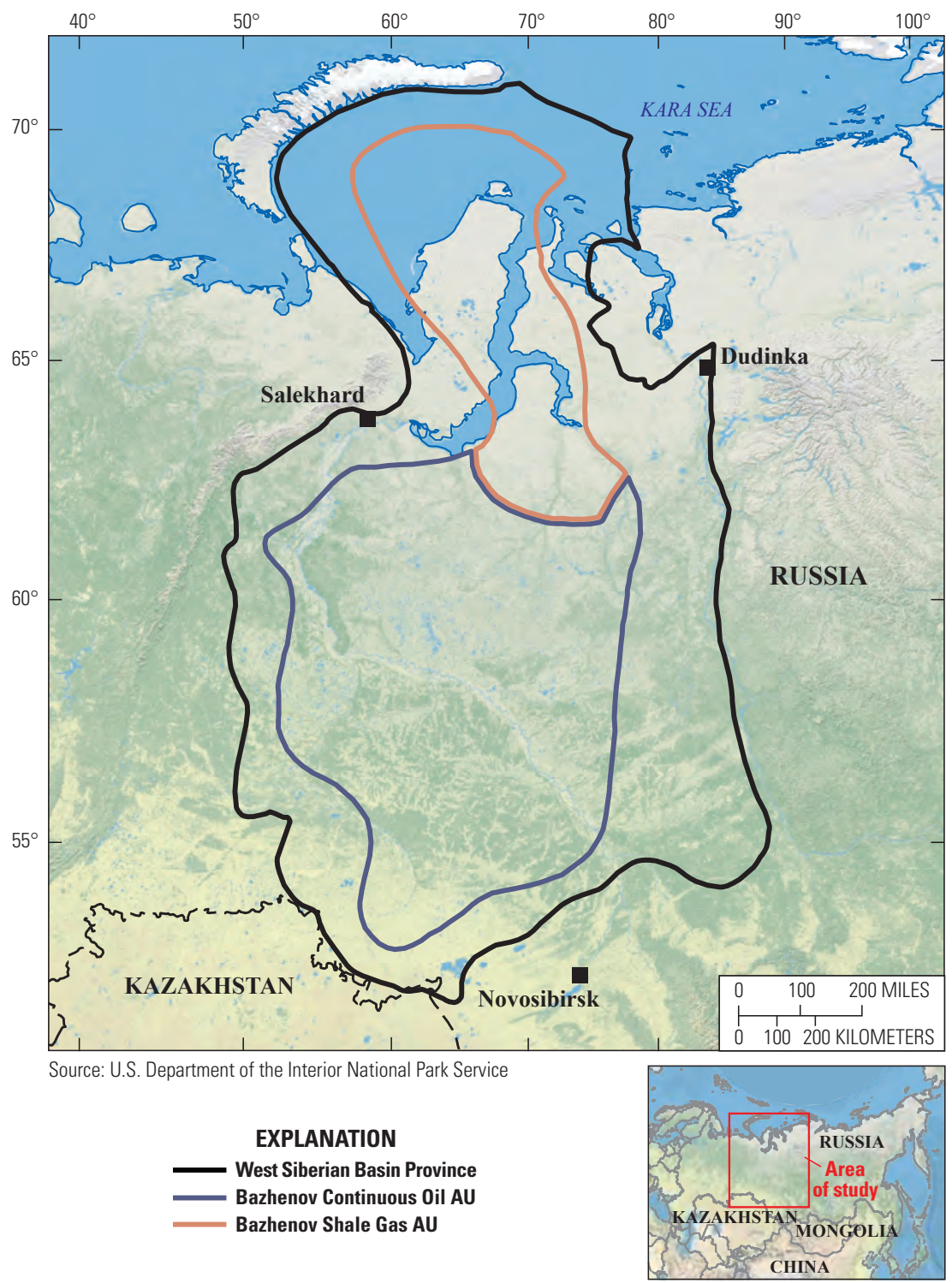

Figure 1. Map showing the Bazhenov Continuous Oil and Bazhenov Shale Gas Assessment Units (AU) in the West Siberian Basin Province, Russia.

States. Specifically, mean estimated ultimate recoveries from populations of continuous oil and shale-gas wells, the mean drainage areas of drilled wells, and ranges of average well success ratios were used to estimate the undiscovered continuous oil and shale-gas resources. Principal input data used in the assessment are listed in table 1 . 


\section{Geologic Model}

Continuous oil production from fractured Bazhenov Formation in the southern part of the basin has been reported. It is a self-sourced, organic-rich mudstone (total organic carbon content of at least 2 weight percent), contains mostly Type II kerogen, and is thermally mature with respect to oil generation (Ulmishek, 2003). The Bazhenov Continuous Oil AU area does not include areas of discovered accumulations and areas where undiscovered conventional accumulations might be present. Discovered continuous oil accumulations were also excluded from the AU. Undiscovered continuous oil accumulations most likely exist between structural highs.

No shale-gas production has been reported from the Bazhenov Formation. However, the part of the Bazhenov Formation in the northern part of the basin is presumed to be similar to that in the southern part of the basin but thermally mature with respect to gas generation. As with the Bazhenov Continuous Oil AU, the Bazhenov Shale Gas AU area does not include areas of discovered and undiscovered conventional fields on structural highs. Undiscovered shale-gas accumulations most likely exist between structural highs.

\section{Undiscovered Resources Summary}

The USGS quantitatively assessed unconventional oil and gas resource in one continuous oil AU and one continuous shale-gas AU in the West Siberian Basin of Russia (table 2). For total undiscovered resources, the estimated means are 12,219 million barrels of continuous oil (MMBO), or 12 billion barrels of oil, with an F95-F5 range from 2,774 to 26,716 MMBO, 75,156 billion cubic feet of natural gas (BCFG), or 75 trillion cubic feet of natural gas, with an F95-F5 range from 17,446 to $159,284 \mathrm{BCFG}$, and 1,615 million barrels of natural gas liquids (MMBNGL) with an F95-F5 range from 354 to 3,602 MMBNGL.

For total continuous oil resources, the estimated means for the Bazhenov Continuous Oil AU are 12,219 MMBO with an F95-F5 range from 2,774 to 26,716 MMBO, 4,888 BCFG with an F95-F5 range from 1,106 to $10,721 \mathrm{BCFG}$, and 69 MMBNGL with an F95-F5 range from 14 to 158 . For total shale-gas resources, the estimated means for the Bazhenov Shale Gas AU are 70,268 BCFG with an F95-F5 range from 16,340 to 148,563 BCFG and 1,546 MMBNGL with an F95-F5 range from 340 to 3,444 MMBNGL.

Table 1. Key assessment input data for the Bazhenov Continuous Oil and Bazhenov Shale Gas Assessment Units (AUs) in the West Siberian Basin Province, Russia.

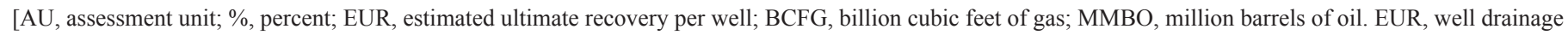

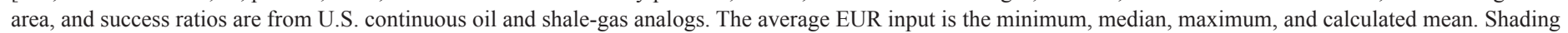
indicates not applicable]

\begin{tabular}{|c|c|c|c|c|c|c|c|c|}
\hline \multirow[b]{2}{*}{ Assessment input data } & \multicolumn{4}{|c|}{ Bazhenov Continuous Oil AU } & \multicolumn{4}{|c|}{ Bazhenov Shale Gas AU } \\
\hline & Minimum & Mode & Maximum & $\begin{array}{c}\text { Calculated } \\
\text { mean }\end{array}$ & Minimum & Mode & Maximum & $\begin{array}{c}\text { Calculated } \\
\text { mean }\end{array}$ \\
\hline Potential production area of AU (acres) & 1,000 & $66,500,000$ & $137,500,000$ & $68,000,333$ & 1,000 & $32,250,000$ & $64,500,000$ & $32,250,333$ \\
\hline Average drainage area of wells (acres) & 120 & 180 & 240 & 180 & 80 & 120 & 160 & 120 \\
\hline Success ratios $(\%)$ & 10 & 50 & 90 & 50 & 10 & 50 & 90 & 50 \\
\hline Average EUR (oil, MMBO; gas, BCFG) & 0.03 & 0.06 & 0.15 & 0.065 & 0.2 & 0.5 & 1.0 & 0.522 \\
\hline AU probability & 1.0 & & & & 1.0 & & & \\
\hline
\end{tabular}

Table 2. Assessment results for the Bazhenov Continuous Oil and Bazhenov Shale Gas Assessment Units (AUs) in the West Siberian Basin Province.

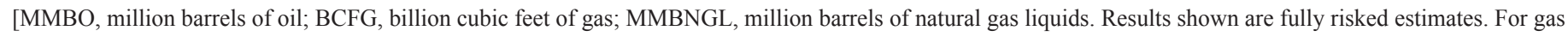

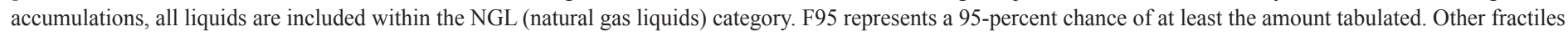
are defined similarly. Fractiles are additive under the assumption of perfect positive correlation. Shading indicates not applicable]

\begin{tabular}{|c|c|c|c|c|c|c|c|c|c|c|c|c|c|c|}
\hline \multirow{3}{*}{$\begin{array}{l}\text { Total petroleum system (TPS) } \\
\text { and assessment units (AUs) }\end{array}$} & \multirow{3}{*}{$\begin{array}{c}\text { AU } \\
\text { prob- } \\
\text { ability }\end{array}$} & \multirow{3}{*}{$\begin{array}{c}\text { Accu- } \\
\text { mulation } \\
\text { type }\end{array}$} & \multicolumn{12}{|c|}{ Total undiscovered resources } \\
\hline & & & \multicolumn{4}{|c|}{ Oil (MMBO) } & \multicolumn{4}{|c|}{ Gas (BCFG) } & \multicolumn{4}{|c|}{ NGL (MMBNGL) } \\
\hline & & & F95 & F50 & F5 & Mean & F95 & F50 & F5 & Mean & F95 & F50 & F5 & Mean \\
\hline \multicolumn{15}{|c|}{ Bazhenov Formation TPS } \\
\hline Bazhenov Continuous Oil AU & 1.0 & Oil & 2,774 & 10,725 & 26,716 & 12,219 & 1,106 & 4,286 & 10,721 & 4,888 & 14 & 58 & 158 & 69 \\
\hline Bazhenov Shale Gas AU & 1.0 & Gas & & & & & 16,340 & 63,131 & 148,563 & 70,268 & 340 & 1,343 & 3,444 & 1,546 \\
\hline Total undiscovered resources & & & 2,774 & 10,725 & 26,716 & 12,219 & 17,446 & 67,417 & 159,284 & 75,156 & 354 & 1,401 & 3,602 & 1,615 \\
\hline
\end{tabular}

\section{References Cited}

Charpentier, R.R., and Cook, T.A., 2011, USGS methodology for assessing continuous petroleum resources: U.S. Geological Survey Open-File Report 2011-1167, 73 p., accessed September 26, 2016, at http://pubs.usgs.gov/of/2011/1167/.

Clarke, J.W., and Rachlin, J., 1980, Salym—Potential W. Siberian oil giant: Oil and Gas Journal, v. 78, no. 24 (June 16, 1980), p. 132-135.

Ulmishek, G.F., 2003, Petroleum geology and resources of the West Siberian Basin, Russia: U.S. Geological Survey Bulletin 2201-G, $49 \mathrm{p}$.

\section{West Siberian Basin Province Assessment Team}

Timothy R. Klett, Christopher J. Schenk, Michael E. Brownfield, Heidi M. Leathers-Miller, Tracey J. Mercier, Janet K. Pitman, and Marilyn E. Tennyson

\section{For More Information}

Assessment results are available at the USGS Energy

Resources Program Web site at http://energy.usgs.gov. 